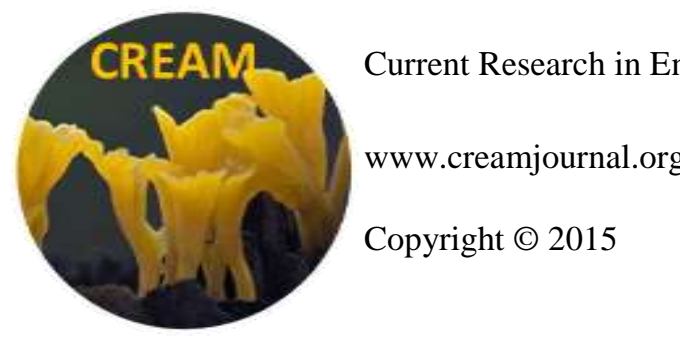

\author{
Article \\ CREAM \\ Online Edition
}

Doi 10.5943/cream/5/1/8

\title{
Elephant dung-inhabiting macrofungi in the Western Ghats
}

\author{
NC Karun and KR Sridhar*
}

Department of Biosciences, Mangalore University, Mangalagangotri, Mangalore 574 199, Karnataka, India

Karun NC, Sridhar KR 2015 - Elephant dung-inhabiting macrofungi in the Western Ghats. Current Research in Environmental \& Applied Mycology 5(1), 60-69, Doi 10.5943/cream/5/1/8

\begin{abstract}
Six species of macrofungi in five genera were documented growing on elephant dung located in the Brahmagiri Wildlife Sanctuary of Western Ghats of Karnataka (Conocybe pubescens, Coprinus patouillardii, Panaeolus fimicola, Podosordaria elephanti, Psilocybe coprophila and P. fimetaria). Among these, Coprinus patouillardii, Panaeolus fimicola and Psilocybe fimetaria are the first record, while Conocybe pubescens is new record on elephant dung in the Western Ghats. Including the present study, so far a total of 31 species of macrofungi have been reported on elephant dung of the Western Ghats. Some of the elephant dung-inhabiting macrofungi were also found on other herbivore dung in the Western Ghats and elsewhere. Future inventories on macrofungi inhabiting on dung of domestic/tamed, conserved and wild elephants to fill our knowledge gap on their diversity and to open up scope to harness their bioactive potential.
\end{abstract}

Key words - herbivore dung - Karnataka - macrofungi - Western Ghats - wildlife sanctuary

\section{Introduction}

Macrofungi are highly valuable throughout the world due their potential role in nutritional, pharmaceutical and industrial applications. They occur in a wide variety of habitats (e.g. grasslands, forests, mangroves and coastal sand dunes) as well as substrates (soil, leaf litter, woody litter and dung). According to Bustillos et al. (2014), hallucinogenic mushroom genera known for psilocybin include Conocybe, Gymnopilus, Panaeolus, Pluteus, Psilocybe and Stropharia. Hallucinoginic compounds of mushrooms are similar to lysergic acid diethylamide eliciting major impact on the central nervous system (Reingardiene et al. 2005). Psychoactive mushrooms are distributed all over the world with highest occurrence in subtropical humid forest ecosystems (Guzman et al. 2000). Besides occurrence of a plethora of microfungi on dung of wild and domestic animals (e.g. Jeamjitt et al. 2006, Mungai et al. 2011, 2012), a variety of macrofungi are known to harbour different herbivore dung (e.g. Manimohan et al. 2007, Doveri 2010, Kaur et al. 2014a). Herbivore dung also constitutes an excellent substrate for a variety of hallucinogenic mushrooms especially Psilocybe spp., which are known for psilocin and psilocybin (Beug 2011). So far, over 150 psilocybincontaining mushrooms belonging to many genera and families have been reported (Bustillos et al. 2014). Among the herbivorous dung, elephant dung is a potential substrate supporting a variety of macrofungi (Pegler 1977, Thomas et al. 2001, Manimohan et al. 2007, Kaur et al. 2014a). Among the mushrooms occurring on elephant dung, large basidiomata-producing Macrocybe gigantea (pileus, 30-35 cm; stipe, 15-18 ×6 cm) was supported by large heaps than isolated elephant 
droppings as it needs a large substratum (Pegler et al. 1998, Manimohan et al. 2007). During expedition of macrofungi of the Western Ghats in sacred groves, forest reserves and national parks of Karnataka, six species of macrofungi were recorded on elephant droppings. It is believed that it is timely to consider updating the reports on macrofungi obtained on elephant dung in the Western Ghats of India. Thus, this paper deals with brief description of six species of macrofungi obtained and provides a list of macrofungi recovered on elephant dung in the Western Ghat region in comparison with other regions.

\section{Materials \& Methods}

During survey of macrofungi in sacred groves, forest reserves and national parks two locations of the Brahmagiri Wildlife Sanctuary, Kodagu region of Karnataka, Western Ghats (Heggala-Thora: $12^{\circ} 7^{\prime} \mathrm{N}, 7^{\circ} 43^{\prime} \mathrm{E}, 935 \mathrm{~m}$ asl; V'Badaga: $12^{\circ} 5^{\prime} \mathrm{N}, 75^{\circ} 50^{\prime} \mathrm{E}, 915 \mathrm{~m}$ asl) consist of elephant dung. Six macrofungi were recovered on examination of elephant droppings, their general features were studied on the collection spot followed by detailed microscopic examinations in the laboratory. Examined macrofungi were deposited in mycological herbarium, Department of Biosciences, Mangalore University, Mangalagangotri, Mangalore.

\section{Results}

Examination of elephant dung yielded five basidiomycetes and one ascomycete. Based on the literature, details of macrofungi reported so far on elephant dung in the Western Ghats (including this study) is given in Table 1. A brief description of six species recovered in the present study with their occurrence on dung, other substrates and distribution are given.

Conocybe pubescens (Gillet) Kühner

(Fig. 1a-b)

Small, reddish-brown, delicate agaric with orange-brown gills and finely pubescent stem; solitary or in small groups, annual, coprophilous, rare, odour and taste not distinctive and inedible.

Pileus $0.6-1.8 \mathrm{~cm}(\mathrm{n}=4)$, at first conical, becoming bell-shaped with striate margin; initially reddish-brown, fading to orange-brown, hygrophanous, drying paler, striate midway towards margin and finely pubescent/fibrillose when young otherwise smooth to silky. Flesh creamish, thin and fragile. Lamellae reddish-brown, becoming orange-brown at maturity, narrow, adnate, fairly distant with short gills of 2-3 lengths. Basidiospores $11.6(10.5-12.5) \times 7.8(7.2-8.2) \mu \mathrm{m}(\mathrm{n}=25)$, orange, smooth and broadly ellipsoidal. Stipe $5.3-6.8 \mathrm{~cm} \times 0.15-0.2 \mathrm{~cm}(\mathrm{n}=4)$, concolorous with cap, slender, equal, finely pubescent/fibrillose when young otherwise smooth and ring absent. Flesh pallid, hollow and fragile.

Substrate and distribution. Elephant dung in Makutta Reserve forest, Virajpet, Kodagu (Karnataka: July 28, 2012; N.C. Karun) (MUBSNCKKRSMF \# 040); evergreen and moist deciduous forests, grasslands and soils of Kerala (Mohanan 2011); Western Ghats of Maharashtra (Sathe \& Deshpande 1980). Present report constitutes new record on elephant dung in the Western Ghats. This is a world-wide distributed dung-inhabiting taxon (Hausknecht et al. 2009), reported on dung or manured soil, Europe (Jordan 1995); horse dung, Britain, Ireland and Italy (Dovari 2010, Buczacki 2012); dung in garden, Uzbekistan (Hausknecht et al. 2009); dung, Estonia (Kalamees et al. 2013). It was also reported on grass in woods and lawns in Europe (Phillips 2006).

Coprinus patouillardii Quél.

(Fig. 1c-d)

Very small, fragile, translucent agaric with smoky-white cap, dark gills and white stem; occur in small groups, annual, coprophilous, infrequent to rare, odour and taste not distinctive and inedible.

Pileus $0.2-0.4 \mathrm{~cm}(\mathrm{n}=5)$, at first ovoid, becoming convex to flattened and upturned with serrate to toothed/broadly sulcate-striate margin; at first smoky white, becoming cinnamon towards the centre with greyish tinge, flaky velar remnants and possess prominent smooth sulcate surface. Flesh very thin, delicate and auto-digesting. Lamellae pale, becoming greyish-black with age, free to adnexed, distant, narrow, regular and devoid of short gills. Basidiospores black, smooth, 


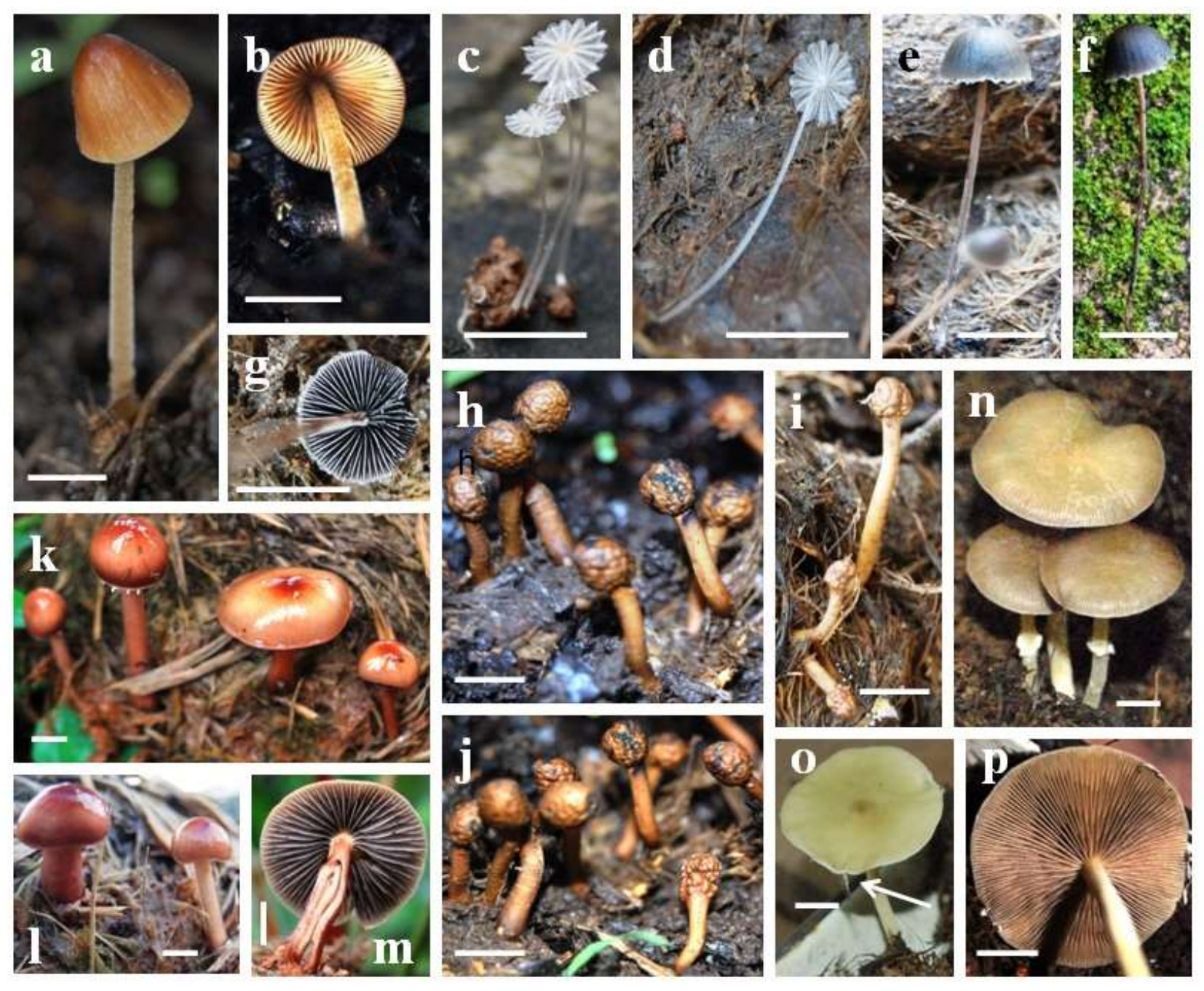

Fig. 1 - Conocybe pubescens (a, b), Coprinus patouillardii (c, d), Panaeolus fimicola (e-g), Podosordaria elephanti $(\mathrm{h}-\mathrm{j})$, Psilocybe coprophila $(\mathrm{k}-\mathrm{m})$ and P. fimetaria $(\mathrm{n}-\mathrm{p} ; \mathrm{o}$, arrow: peeling of separable skin).

narrowly ellipsoidal $8.6(7.8-9.9) \times 3.8(3.0-4.7) \mu \mathrm{m}$. Stipe $1.1-1.6 \mathrm{~cm} \times \leq 0.1 \mathrm{~cm}(\mathrm{n}=5)$, white, semi-translucent, slender, long and minutely flaky. Flesh brittle and delicate.

Substrate and distribution. Elephant dung of Heggala-Thora, Virajpet, Kodagu (Karnataka: July 29, 2012; N.C. Karun) (MUBSNCKKRSMF\#041). This is the first record on elephant dung in the Western Ghats. It also occurred on dung in Britain and Ireland (Buczacki 2012) and manure in Europe (Jordan 1995).

Panaeolus fimicola (Pers.) Gillet

(Fig. 1e-g)

Small, greyish agaric with mottled black gills and purple-brown stem; solitary or in small groups, annual, coprophilous, infrequent, odour and taste not distinctive and inedible.

Pileus $0.4-1.2 \mathrm{~cm}(\mathrm{n}=5)$, at first parabolic becoming hemispherical with slight umbo with veler remnants overhanging the margin as fine regularly spaced teeth; at first greyish-brown fading to greyish with hazel tinge, hygrophanous, smooth, finely crazed and wrinkled. Flesh grey and thin. Lamellae at first grey-olivaceous, becoming mottled black with white edge, adnate, moderately crowded, narrow, regular and short gills of 2 lengths. Basidiospores $6.89(6.587 .36) \times 5.86(5.26-$ $6.58) \mu \mathrm{m}$. $(\mathrm{n}=25)$, purple black, smooth and lemon-shaped to angular with an apical germ-pore. Stipe $1.8-5.6 \times \leq 0.1 \mathrm{~cm}(\mathrm{n}=5)$, purple-brown/clay, slender, long, equal and finely pruinose. Flesh pallid brown, hollow and fragile. 
Table 1 Elephant dung-inhabiting macrofungi from the Western Ghats (*New and **first record on elephant dung in the Western Ghats).

\begin{tabular}{|c|c|c|}
\hline Taxon & Elephant dung (Western Ghats) & $\begin{array}{l}\text { On dung or other substrates } \\
\text { (Western Ghats and outside: not } \\
\text { exhaustive) }\end{array}$ \\
\hline \multicolumn{3}{|l|}{ Agaricaceae } \\
\hline **Coprinus patouillardii Quél. & $\begin{array}{l}\text { Karnataka, first record for the } \\
\text { Western Ghats (Present study) }\end{array}$ & $\begin{array}{l}\text { Dung, Britain and Ireland (Buczacki } \\
\text { 2012) }\end{array}$ \\
\hline \multicolumn{3}{|l|}{ Bolbitiaceae } \\
\hline $\begin{array}{l}\text { Agrocybe guruvayoorensis K.A. } \\
\text { Thomas \& Manim. }\end{array}$ & Kerala (Manimohan et al. 2007) & - \\
\hline Agrocybe pediades (Fr.) Fayod & Kerala ( Mohanan 2011) & $\begin{array}{l}\text { Cattle dung, Kerala (Mohanan 2011); } \\
\text { horse dung, Italy (Doveri 2010); }\end{array}$ \\
\hline Bolbitius coprophilus (Peak) Hongo & $\begin{array}{l}\text { Kerala (Thomas et al. 2001, } \\
\text { Manimohan et al. 2007) }\end{array}$ & $\begin{array}{l}\text { Open area on grass, Punjab (Atri et al. } \\
\text { 1992); buffalo dung, Punjab } \\
\text { (Amandeep et al. 2013); elephant dung, } \\
\text { East Africa (Pegler 1977); horse dung, } \\
\text { Italy (Doveri 2010); horse manure, } \\
\text { Austria (Hausknecht \& Krisai- } \\
\text { Greilhuber 2003) }\end{array}$ \\
\hline $\begin{array}{l}\text { Conocybe brunneoaurantiaca K.A. } \\
\text { Thomas \& Manim. }\end{array}$ & Kerala (Manimohan et al. 2007) & - \\
\hline Conocybe pseudopubescens K.A. & Kerala (Thomas et al. 2001, & - \\
\hline $\begin{array}{l}\text { *Conocybe pubescens (Gillet) } \\
\text { Kühner }\end{array}$ & $\begin{array}{l}\text { Karnataka, new record on elephant } \\
\text { dung in the Western Ghats (Present } \\
\text { study) }\end{array}$ & $\begin{array}{l}\text { Soil, grasslands, evergreen/moist } \\
\text { deciduous forests, Kerala (Mohanan } \\
\text { 2011); Western Ghats of Maharashtra } \\
\text { (Sathe \& Deshpande 1980); horse } \\
\text { dung, Italy (Dovari 2010); horse dung, } \\
\text { Britain and Ireland (Buczacki 2012); } \\
\text { dung, Uzbekistan (Hausknecht et al. } \\
\text { 2009); dung, Estonia (Kalamees et al. } \\
\text { 2013) }\end{array}$ \\
\hline $\begin{array}{l}\text { Conocybe volvata K.A. Thomas \& } \\
\text { Manim. }\end{array}$ & $\begin{array}{l}\text { Kerala (Thomas et al. 2001, } \\
\text { Manimohan et al. 2007) }\end{array}$ & - \\
\hline $\begin{array}{l}\text { Copelandia cyanescens (Berk. \& } \\
\text { Broome) Singer }\end{array}$ & Kerala ( Manimohan et al. 2007) & - \\
\hline Panaeolina rhombisperma Hongo & Kerala (Manimohan et al. 2007) & - \\
\hline Panaeolus acuminatus Quél. & Kerala (Vrinda et al. 1999) & $\begin{array}{l}\text { Cattle dung, Punjab (Kaur et al. } \\
\text { 2014a); cattle dung, Italy (Doveri } \\
\text { 2010) }\end{array}$ \\
\hline Panaeolus antillarum (Fr.) Dennis & $\begin{array}{l}\text { Tamil Nadu (Natarajan \& Raaman, } \\
\text { 1983); Kerala (Manimohan et al. } \\
\text { 2007, Mohanan 2011) }\end{array}$ & $\begin{array}{l}\text { Cattle dung, Punjab (Kaur et al. } \\
\text { 2014a); elephant, buffalo, cattle, horse } \\
\text { and rhinoceros dung, South Africa } \\
\text { (Reid \& Eicker 1999); cow dung, } \\
\text { Kenya (Pegler 1977); elephant and } \\
\text { buffalo dung, Uganda (Pegler 1997); } \\
\text { cow dung, China (Zhishu et al. 1993); } \\
\text { cattle and horse dung, East Falkland } \\
\text { (Watling \& Richardson 2010); horse } \\
\text { manure, Australia (Hausknecht \& } \\
\text { Krisai-Greilhuber 2003); cattle dung, } \\
\text { Italy (Doveri 2010) }\end{array}$ \\
\hline **Panaeolus fimicola (Pers.) Gillet & $\begin{array}{l}\text { Karnataka, first record for the } \\
\text { Western Ghats (Present study) }\end{array}$ & $\begin{array}{l}\text { Soil among grass/lawns, Europe } \\
\text { (Jordan 1995, Phillips 2006, Buczacki } \\
\text { 2012) }\end{array}$ \\
\hline Panaeolus rickenii Hora & Kerala (Manimohan et al. 2007) & - \\
\hline $\begin{array}{l}\text { Pholiotina indica K.A. Thomas \& } \\
\text { Manim. }\end{array}$ & $\begin{array}{l}\text { Kerala (Thomas et al. 2001, } \\
\text { Manimohan et al. 2007, Mohanan } \\
\text { 2011) }\end{array}$ & - \\
\hline
\end{tabular}




\begin{tabular}{|c|c|c|}
\hline Taxon & Elephant dung (Western Ghats) & $\begin{array}{l}\text { On dung or other substrates } \\
\text { (Western Ghats and outside: not } \\
\text { exhaustive) }\end{array}$ \\
\hline \multicolumn{3}{|l|}{ Entolomataceae } \\
\hline $\begin{array}{l}\text { Entoloma anamikum Manim., A.V. } \\
\text { Joseph \& Leelav. } \\
\text { Pluteaceae }\end{array}$ & $\begin{array}{l}\text { Kerala (Manimohan et al. 2007, } \\
\text { Noordeloos et al. 2007) }\end{array}$ & - \\
\hline $\begin{array}{l}\text { Volvariella volvacea (Bull.) Singer } \\
\text { Psathyrellaceae }\end{array}$ & Kerala (Manimohan et al. 2007) & - \\
\hline $\begin{array}{l}\text { Psathyrella conopilus (Fr.) A. } \\
\text { Pearson \& Dennis } \\
\text { Strophariaceae }\end{array}$ & Kerala (Vrinda et al. 1999) & - \\
\hline $\begin{array}{l}\text { Psilocybe coprophila (Bull.) P. } \\
\text { Kumm. }\end{array}$ & $\begin{array}{l}\text { Kerala (Manimohan et al. 2007); } \\
\text { Karnataka (Present study) }\end{array}$ & $\begin{array}{l}\text { Cow, horse and sheep dung, Europe } \\
\text { (Jordan 1995); dung, Europe (Phillips } \\
\text { 2006); sheep dung, Britain and Ireland } \\
\text { (Buczacki 2012) }\end{array}$ \\
\hline Psilocybe argentina (Speg.) Singer & Kerala (Mohanan 2011) & - \\
\hline **Psilocybe fimetaria (P.D. Orton) & Karnataka, first record for the & Horse dung, Europe (Jordan 1995); \\
\hline Watling & Western Ghats (Present study) & $\begin{array}{l}\text { horse dung, Britain and Ireland } \\
\text { (Buczacki 2012) }\end{array}$ \\
\hline Psilocybe inquilina (Fr.) Bres. & Kerala (Mohanan 2011) & 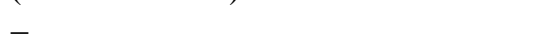 \\
\hline Psilocybe pegleriana Guzmán & $\begin{array}{l}\text { Kerala (Manimohan et al. 2007, } \\
\text { Mohanan 2011) }\end{array}$ & - \\
\hline Psilocybe subaeruginascens Höhn. & Kerala (Manimohan et al. 2007) & Wild pig dung, Italy (Doveri 2010) \\
\hline Psilocybe subcubensis Guzmán & $\begin{array}{l}\text { Kerala (Manimohan et al. 2007, } \\
\text { Mohanan 2011) }\end{array}$ & - \\
\hline Stropharia bicolor Pegler & Kerala (Manimohan et al. 2007) & $\begin{array}{l}\text { Elephant dung, East Africa (Pegler } \\
\text { 1977) }\end{array}$ \\
\hline $\begin{array}{l}\text { Stropharia rugosoannulata Farl. ex } \\
\text { Murrill }\end{array}$ & Kerala (Manimohan et al. 2007) & - \\
\hline $\begin{array}{l}\text { Stropharia semiglobata (Batsch) } \\
\text { Quél. }\end{array}$ & Kerala (Mohanan 2011) & $\begin{array}{l}\text { Dung, Europe (Jordan 2005; Phillips } \\
\text { 2006); dung, Britain and Ireland } \\
\text { (Buczacki 2012) }\end{array}$ \\
\hline $\begin{array}{l}\text { Tricholomataceae } \\
\text { Macrocybe gigantea (Massee) } \\
\text { Pegler \& Lodge } \\
\text { Xylariaceae }\end{array}$ & Kerala (Manimohan et al. 2007) & - \\
\hline $\begin{array}{l}\text { Podosordaria elephanti J.D. Rogers } \\
\& \text { Y.M. Ju }\end{array}$ & $\begin{array}{l}\text { Kerala (Deepna \& Manimohan, } \\
\text { 2012); Karnataka (Present study) }\end{array}$ & - \\
\hline Poronia pileiformis (Berk.) Fr. & $\begin{array}{l}\text { Kerala (Deepna \& Manimohan } \\
\text { 2012) }\end{array}$ & $\begin{array}{l}\text { Dung, Meghalaya (Rawla \& Narula } \\
\text { 1983) }\end{array}$ \\
\hline
\end{tabular}

Substrate and distribution. Elephant dung in Makutta Reserve forest, Virajpet, Kodagu (Karnataka: August 20, 2012; N.C. Karun) (MUBSNCKKRSMF \# 042). This is the first record on elephant dung in the Western Ghats. It also occurred in soil among grass/lawns, Europe (Jordan 1995, Phillips 2006, Buczacki, 2012).

Podosordaria elephanti J.D. Rogers \& Y.M. Ju

(Fig. 1h-j)

Small, pale, orange-brown, more or less round fertile head surmounting a tough concolorous sterile stem; gregarious or in small troops, annual, coprophilous, rare, odour and taste not distinctive and inedible.

Stromata lolly pop-like/round-headed hammer/single-headed dumbbell-like; upper stromatal surface at first orange brown fading to yellowish brown with a subglobose fertile head $0.4-0.7 \mathrm{~cm}$ $(n=25)$, reticulated, grooved, warty, decorated with numerous innate black papillate ostioles, narrowing/stretching to concolorous, small to medium, cylindrical, concentrically striate and smooth sterile stem firmly attached to the substratum: $1.1-2.2 \times 0.15-0.3 \mathrm{~cm}(\mathrm{n}=25)$. Perithecia black, sub-spherical, fully embedded in fertile region (head) of stromatal tissue and arranged in single dense layer just below the surface with papillate ostioles. Flesh creamish, thick and firm. Asci cylindrical/club-shaped: $101.4(89.4-121.0) \times 4.8(4.5-5.3) \mu \mathrm{m}(\mathrm{n}=25)$. Ascospores eight, black, 
smooth, fusiform, flattened on one side with distinct cleft, non-septate and uniseriate: 10.1 ( $9.2-$ $10.5) \times 4.6(4.4-4.7) \mu \mathrm{m}(\mathrm{n}=25)$.

Substrate and distribution. Elephant dung in Makutta Reserve Forest, Virajpet, Kodagu (Karnataka: July 28, 2012; N.C. Karun) (MUBSNCKKRSMF \# 043); elephant dung in Kerala (Deepna \& Manomohan, 2012). This is the third record after original description by Rogers et al. (1998) and report by Deepna \& Manimohan (2012).

Psilocybe coprophila (Bull.) P. Kumm.

(Fig. 1k-m)

Small reddish-brown agaric with viscid domed cap and stem, and greyish-brown gills; solitary or in small groups, annual, coprophilous, rare, odour and taste not distinctive and inedible.

Pileus 1.7-4.7 cm ( $\mathrm{n}=5)$, at first bell-shaped or convex-campanulate becoming convex with a prominent umbo and smooth, straight margin; at first reddish-brown, fading to tawny-brown, covered with detachable viscid layer when young and just matured otherwise greasy with velar fragments. Flesh pallid and thin. Lamellae greyish-brown, broad, emarginate or adnate, moderately crowded and short gills of 3-4 lengths. Basidiospores $11.8(10.8-12.9) \times 8.2(7.4-9.2) \mu \mathrm{m}(\mathrm{n}=25)$, purple-brown, smooth, lemon shaped to broadly ellipsoidal and with an apical germ pore. Stipe 3.6$7.3 \times 0.3-0.7 \mathrm{~cm}(\mathrm{n}=5)$, central, concolorous or flushed with cap color, covered with detachable viscid layer when young, otherwise smooth, greasy with velar fragments, short to long and more or less equal or slightly tapering towards the apex. Ring absent. Flesh pallid, fibrous and stuffed.

Substrate and distribution. Elephant dung in Shola Forest of Heggala-Thora, Virajpet, Kodagu (Karnataka: July 29, 2012; N.C. Karun) (MUBSNCKKRSMF \# 044), elephant dung in Kerala (Manimohan et al. 2007). It also occurred on dung (Phillips 2006), cow, horse and sheep dung in Europe (Jordan 1995); sheep dung, Britain and Ireland (Buczacki 2012).

Psilocybe fimetaria (P.D. Orton) Watling

(Fig. 1n-p)

Small, pale greenish-yellow agaric with greasy convex cap, purple-brown gills and slender stem with ring (only in young specimens); solitary or in small groups, annual, coprophilous, rare, odour and taste not distinctive and inedible.

Pileus 1.3-3.8 $(\mathrm{n}=4)$, at first hemispherical or broadly bell-shaped, becoming convex with a prominent umbo and striate/lined margin; at first date-brown with olivaceous tinge, fading to pale greenish yellow with peeling of tough separable skin is unique and greasy/viscid when moist (Fig. 1o, arrow). Flesh pale and thin. Lamellae purple-brown, broad, emarginate/adnate and moderately crowded with short gills of 4 lengths. Basidiospores $8.3(7.4-9.2) \times 7.0(6.6-7.9) \mu \mathrm{m}(\mathrm{n}=25)$, purple, smooth, lemon-shaped to angular and with an apical germ-pore. Stipe 4.2-11.3 $\times 0.15-0.4$ $\mathrm{cm}(\mathrm{n}=4)$, central, pallid, concolorous or flushed with cap color, smooth, fibrillose, slender and more or less equal or slightly tapering towards the apex. Ring present, upturned and seen only in young samples otherwise ephemeral white zone.

Substrate and distribution. Elephant dung in Shola Forest, Heggala-Thora, Virajpet, Kodagu (Karnataka: September 07, 2012; N.C. Karun) (MUBSNCKKRSMF \# 045). This the first record on elephant dung in the Western Ghats. It also occurred on horse dung, Europe, Britain and Ireland (Jordan 1995, Buczacki 2012).

\section{Discussion}

Details of macrofungi recorded on the elephant dung so far in the Western Ghats of India (Karnataka, Kerala and Tamil Nadu) with remarks on their occurrence on other dung and substrates are given in Table 1. Including the present study, 31 species (16 genera in 8 families) were recorded with a highest of 27 species in Kerala followed by six species in Karnataka and one species in Tamil Nadu (Natarajan \& Raman 1983, Vrinda et al. 1999, Thomas et al. 2001, Manimonan et al. 2007, Noordeloos et al. 2007, Mohanan 2011, Deepna \& Manimohan 2012). Species of Psilocybe were highest ( 7 species) followed by Conocybe and Panaeolus (4 species each), Stropharia (3 species), Agrocybe (2 species) and the rest 11 species represented by single species. 
Manimohan et al. (2007) reported five macrofungi exclusively growing on elephant dung (Agrocybe guruvayoorensis, Conocybe pseudopubescens, C. volvata, Pholiotina indica and Stropharia bicolor). Among them, S. bicolor was also reported on elephant dung in East Africa (Pegler 1977). Among worldwide known Bolbitius, as many as 10 species have been reported from India with recent addition of three more species on herbivorous dung from Punjab (Amandeep et al. 2013). Conocybe pubescens has wide distribution, besides its occurrence on elephant dung it is known from soils, grasslands, evergreen/moist deciduous forests of Kerala and Maharashtra (Sathe \& Deshpande 1980, Mohanan 2011). Nearly 26 species of Panaeolus have been reported from India and up to 18 species on a variety of dung from Punjab alone (Kaur et al. 2014a, 2014b). Panaeolus africanus grew on elephant and hippopotamus dung in Central and South Africa (Stamets 1996). Interestingly, Stropharia rugosoannulata although known from temperate and rarely in subtropics (on decomposing straw, mulch, soil and litter) (Cortez \& Coelho 2004), all collections from Kerala were confined only to elephant dung (Manimohan et al. 2007).

Besides the genera of macrofungi listed in Table 1, a variety of macrofungi grew on dung materials in India (e.g. Agaricus, Boletus, Lepista and Protostropharia). Two new species Agaricus stellatus-cuticus and A. flavistipus were reported on sheep dung in Punjab (Kaur et al. 2014c). The edible mushroom Boletus luteus occurred on elephant dung-infested soil in Assam (Sarma et al. 2010). Lepista sordida also grew on elephant dung manure in Deer park of Chennai, Tamil Nadu (Natarajan \& Raman 1980). The edible Protostropharia semiglobata was common on dung (cattle, horse, rabbit and sheep) in British Isles (Arora 1986, Walting \& Gregory 1987) and on the horse dung in Brazil (Cortez \& Coelho 2004). This fungus commonly occurs on dung in Southern India (Natarajan \& Raman 1983, Bhavanidevi 1995) as well as on camel dung in Northern India (Punjab) (see Kaur et al. 2013). Besides, a new variety of $P$. semiglobata (P. semiglobata var. punjabensis) on cow dung in Punjab reported by Kaur et al. (2013) expanded the potential of edible mushrooms on dung.

Some genera of Xylariaceae are coprophilous (e.g. Areolospora, Hypocopra, Podosordaria, Poronia and Wawelia) in spite of many occurring on decaying wood, leaf litter, fruits and seeds (Hsieh et al. 2010, Deepna \& Manimohan 2012). Occurrence of Podosordaria elephanti in the present study constitutes third report after Thailand (Rogers et al. 1998) and India (Deepna \& Manimohan 2012). Another xylariaceous species Poronia pileiformis occurred on dung in Meghalaya and widely distributed on elephant dung in Kerala (Rawla \& Narula 1983, Deepna \& Manimohan 2012). Besides India, this fungus has distribution in Costa Rica, Peru, Philippines and Taiwan (see Deepna \& Manimohan 2012). An endangered Poronia punctata has been reported from Mediterranean grassland of the maritime slopes of Croatia (Matočec, 2000). Besides, it also occurred on cow, donkey, elephant and horse/mule dung (Fries 1823).

It is worth demarcating diversity and potential of coprophilous macrofungi on dung of domestic/tamed (e.g. temples and zoo), conserved (e.g. national parks) and wild (e.g. reserve forests and wild life sanctuaries) herbivores as their milieu vary. In Kerala, elephant dung was examined for macrofungi in several forests of the Western Ghats including Silent Valley National Park and Mathunga Wildlife Sanctuary (Thomas et al. 2001, Manimohan et al. 2007, Deepna \& Manimohan, 2012). The present study confined only on the Brahmagiri Wildlife Sanctuary of Kodagu region in Karnataka. Thus, there is wide scope to survey the elephant corridors in Karnataka like Nagarahole reserve forest, Pushpagiri and Talakaveri Wildlife Sanctuaries (Kodagu); Belthangadi, Subramanya and Sullia (Dakshina Kannada); Agumbe, Karkala and Kundapura (Udupi); Anshi National Park and Dandeli (Uttara Kannada); Konanur and Shakaleshpur (Hassan); Bhadra Wildlife Sanctuary and Kudremukh National Park (Chikamagalur); Sharavathi Wildlife Sanctuary (Shimoga); Bandipur National Park and Kabini back water forest (Mysore); Sathyamangala forest (Chamrajanagar).

Kaur et al. (2014a) proposed need for management of livestock and pastures in conservation of coprophilous macrofungi for future benefit. For instance, Poronia punctata in Croatia became endangered due to replacement of traditional nomadic stockbreeding of horse and donkey population with intensive stockbreeding indoors without allowing grazing in open pastures (see 
Matočec 2000). Due to lack of suitable substrate on grassland in such locations, P. punctata is confined only to those locations not suitable for intensive stockbreeding (e.g. Dalmatia on the Adriatic islands). In view of potential of wild strains of Panaeolus antillarum and P. cyanescens isolated from Philippines, substantial quantities of mycelia and fruit bodies were induced on carabao and cow dung-derived media by Bustillos et al. (2014). Besides testing individual herbivore dung, evaluation of mixed dung on growth, production of fruit bodies and bioactive potential of coprophilous macrofungi will be highly rewarding.

\section{Acknowledgements}

The authors are grateful to Mangalore University for permission to carry out this study in the Department of Biosciences. We appreciate field assistance by Padeyanda Subramani and Kumbera Poovaiah. NCK acknowledges Mangalore University for partial fellowship under the Promotion of University Research and Scientific Excellence (PURSE), Department of Science Technology, New Delhi, India. KRS acknowledges the award of UGC-BSR Faculty Fellowship by the University Grants Commission, New Delhi.

\section{References}

Amandeep K, Atri NS, Munruchi K. 2013 - Diversity of species of the genus Bolbitius (Bolbitiaceae, Agaricales) collected on dung from Punjab, India. Mycosphere 4, 1053-1064.

Arora D. 1986 - Mushrooms Demystified: A Comprehensive Guide to the Fleshy Fungi. Ten Speed Press, Berkeley, California.

Atri NS, Saini SS, Kaur G. 1992 - Taxonomic studies on some members of family Bolbitiaceae Sing. from Punjab. Journal of the Indian Botanical Society 71, 87-89.

Beug MW. 2011 - The genus Psilocybe in North America. Fungi 4, 6-17.

Bhavanidevi S. 1995 - Mushroom flora of Kerala. In: Advances in Horticulture, Volume \# 13 Muhsrooms, Chadha KL, Sharma SR (Ed.). Malhotra Publishing House, New Delhi, 277316.

Buczacki S. 2012 - Collins Fungi Guide. Harper-Collins Publishers, London.

Bustillos RG, Dulay RMR, Kalaw SP, Reyes RG 2014 - Optimization of culture conditions for mycelial growth and basidiocarp production of Philippine strains of Panaeolus antillarium and Panaeolus cyanescens. Mycosphere 5, 398-404.

Cortez VG, Coelho G. 2004 - The Stropharioideae (Strophariaceae, Agaricales) from Santa Maria, Rio Grande do Sul, Brazil. Mycotaxon 89, 355-378.

Deepna LKP, Manimohan P 2012 - Two remarkable xylariaceous ascomycetes associated with elephant dung. Mycosphere 3, 261-265

Doveri F 2010 - Occurrence of coprophilous Agaricales in Italy, new records, and comparisons with their European and extraeuropean distribution. Mycosphere 1, 103-140.

Fries E. 1823 - Systema Mycologicum \# 2. Uppsala.

Guzman G, Allen JW, Gartz J. 2000 - A worldwide geographical distribution of the neurotropic fungi, an analysis and discussion. Annali del Museo Civico di Rovereto: Sezione Archeologia, Storia, Scienze Naturali 14, 189-280.

Hausknecht A, Krisai-Greilhuber I. 2003 - Pilzbeobachtungen in einem neu geschaffenen Weidegebiet. Österreichische Zeitschrift für Pilzkunde 12, 101-123.

Hausknecht A, Kalamees K, Knudsen H, Mukhin V. 2009 - The genera Conocybe and Pholiotina (agaricomycotina, Bolbitiaceae) in temperate Asia. Folia Cryptogamica Estonica 45, 23-47.

Hsieh H, Lin C, Fang M, Rogers JD, Fournier J, Lechat C, Ju Y. 2010 - Phylogenetic status of Xylaria subgenus Pseudoxylaria among taxa of the subfamily Xylarioideae (Xylariaceae) and phylogeny of the taxa involved in the subfamily. Molecular Phylogenetics and Evolution 54, 957-969.

Jeamjitt O, Manoch L, Visarathanonth N, Chamswarng C. 2006 - Diversity and distribution of hyphomycetes from dung in Thailand. Kasetsart Journal (Natural Science) 40, 890-901. 
Jordan M. 1995 - The Encyclopedia of Fungi of Britain and Europe. David and Charles Book Company Devon.

Kalamees K, Hausknecht A, Vauras J. 2013 - Checklist of the genera Conocybe and Pholiotina (Agaricales, Agaricomycetes) in Estonia. Folia Cryptogamica Estonica 50, 33-39.

Kaur A, Kaur M, Atri NS. 2013 - Protostropharia semiglobata var. punjabensis: A new coprophilous agaric from India. Kavaka 41, 11-14.

Kaur A, Atri NS, Kaur M. 2014a - Diversity of coprophilous species of Panaeolus (Psathyrellaceae, Agaricales) from Punjab, India. Biodiversitas 15, 115-130.

Kaur A, Atri NS, Kaur M. 2014b - Two new species of Panaeolus (Psathyrellaceae, Agaricales) from copropholous habitats of Punjab, India. Journal of New Biological Reports 3, 125-132.

Kaur A, Atri NS, Kaur M. 2014c - Two new species of Agaricus (Agaricaceae, Agaricales) collected on dung from Punjab, India. Kavaka, 42, 20-24.

Manimohan P, Thomas KA, Nisha VS. 2007 - Agarics on elephant dung in Kerala State, India. Mycotaxon 99, 147-157.

Matočec N. 2000 - The endangered European species Poronia punctata (Xylariales, Ascomycotina) still alive and well in Croatia. Natura Croatica 9, 35-40.

Mohanan C. 2011 - Macrofungi of Kerala. KFRI Handbook \# 27, Kerala Forest Research Institute, Peechi, Kerala, India.

Mungai P, Hyde KD, Cai L, Njogu J, Chukeatirote K 2011 - Coprophilous ascomycetes of northern Thailand. Current Research in Environmental \& Applied Mycology 1, 135-159.

Mungai PG, Chukeatirote E, Njogu JG, Hyde KD 2012 - Coprophilous ascomycetes in Kenya: Saccobolus species from wildlife dung. Mycosphere 3, 111-129

Natarajan K, Raman N. 1980 - South Indian agaricales-IX. Sydowia 33, 225-235.

Natarajan K, Raman N. 1983 - South Indian Agaricales: A Preliminary Study on Some Dark Spored Species. Bibliotheca Mycologica \# 89, J. Cramer, Germany.

Noordeloos ME, Vrinda KB, Manimohan P. 2007 - On two remarkable brown-spored agarics from Kerala State, India. Fungal Diversity 27, 145-155.

Pegler DN. 1977 - A preliminary agaric flora of East Africa. Kew Bulletin, Additional Series 6, 1615.

Pegler DN, Lodge DJ, Nakasone KK. 1998 - The pantropical genus Macorcybe gen. nov. Mycologia 90, 494-504.

Phillips R. 2006 - Mushrooms. Pan Macmillan, London.

Rawla GS, Narula AM. 1983 - Poronia pileiformis (Berk.) Fr.: A new record from India. Current Science 52, 990.

Reid DA, Eicker A. 1999 - South African fungi 10, new species, new records and some new observations. Mycotaxon 73, 169-197.

Reingardiene D Vilcinskaite J, Lazauskas R. 2005 - Hallucinogenic mushrooms. Clinic of Intensive Therapy. Kaunas University of Medicine, Kaunas, Lithuania 41, 1067-1070.

Rogers JD, Ju Y-M, Martin FS. 1998 - Podosordaria: a redefinition based on cultural studies of the type species, P. mexicana, and two new species. Mycotaxon 67, 61-72.

Sarma TC, Sarma I, Patiri BN. 2010 - Wild edible mushrooms used by some ethnic tribes of Western Assam. The Bioscan 3, 613-625.

Sathe AV, Deshpande S. 1980 - Agaricales (Mushrooms) of Maharashtra State. In: Agaricales (Mushrooms) of South West India. Maharashtra Association for the Cultivation of Science, Research Institute, Pune, India 9-42.

Stamets P. 1996 - Psilocybin Mushrooms of the World. Ten Speed Press, Berkeley.

Thomas KA, Hausknecht A, Manimohan P. 2001 - Bolbitiaceae of Kerala State, India: New species and new and noteworthy records. Österreichische Zeitschrift für Pilzkunde 10, 87-114.

Vrinda KB, Pradeep CK, Mathew S, Abraham TK. 1999 - Agaricales from Western Ghats-VI. Indian Phytopathology 52, 198-200.

Walting R, Gregory NM. 1987 - British Fungus Flora - Agarics and Boleti 5. Strophariaceae and Coprinaceae. Royal Botanic Gardens, Edinburgh. 
Watling R, Richardson MJ. 2010 - Coprophilous fungi of the Falkland Islands. Edinburgh Journal of Botany 67, 399-423.

Zhishu B, Guoyang Z, Taihui L. 1993 - The Macrofungus Flora of China's Guangdong Province. The Chinese University Press, China. 